\title{
Ancient crust on Pacific plate
}

\author{
Leg 129 shipboard scientific party*
}

AFTER a twenty-year search, oceanic crust and sediments dating from the Jurassic have been discovered beneath the deep western Pacific Ocean by Leg 129 of the Ocean Drilling Program (ODP). The oldest sediment recovered is about 170 million years old and is from the base of the Callovian Stage of the Middle Jurassic. This is equivalent to the oldest crustal section to have been recovered from beneath the world's oceans.

Mapping ${ }^{1}$ of magnetic anomalies in the western Pacific has revealed undated magnetic lineations, presumably of Mesozoic age (between 160 and 165 million years old), that might be the oldest magnetic anomalies remaining in any of the Earth's ocean basins. These lineations in the Pigafetta and East Mariana basins are bordered by magnetic 'quiet zones' which are potentially the oldest areas of the Pacific plate. It has been suggested ${ }^{2}$ that an area equal in size to the continental United States or western Europe may be underlain by Jurassic sediments and oceanic crust (see figure), but no evidence of that has ever been recovered from the region, despite the attempts of eight scientific ocean drilling expeditions since 1969 and numerous dredging expeditions going back as far as the 1950s. Instead, the oldest material recovered has almost invariably been the remains of a huge, offridge volcanic event which blanketed the area with thick layers of dolerite sills, basaltic flows and volcaniclastic sediments in the early to mid-Cretaceous, between 80 and 120 million years ago.

Multichannel seismic reflection profiling throughout the deep basins of the western Pacific ${ }^{3}$ has revealed 'windows' through this Cretaceous volcanic pile, providing us with an opportunity for complete penetration into the supposed, original oceanic crust. With the help of * Co-Chief Scientists: Yves Lancelot (Dept de Géologie Dynamique, Univ. Pierre et Marie Curie, Paris) and Roger Larson (Grad. Sch. of Oceanogr., Univ. Rhode Island). ODP Staff Scientist: Andrew Fisher (ODP, Texas A\&M Univ.). Also: Lewis Abrams (Univ. Rhode Island), Richard Behl (Univ. California, Santa Cruz), William Busch (Univ. New Orleans), Gordon Cameron (Dartmouth, Nova Scotia), Paterno Castillo (Univ. Miami), Mitch Covington (Florida State Univ.), Gabi Dürr (Univ. Tübingen), Elisabetta Erba (Univ. degli Studi di Milano), Peter Floyd (Univ. Keele), Christian France-Lanord (Centre de Recherches Pétrographiques et Géochimiques, Vandoeuvre), Ernst Hauser (Univ. München), Susan Karl (U.S. Geol. Survey, Anchorage), Anne-Marie Karpoff (inst. de Géologie, Strasbourg), Atsushi Matsuoka (Niigata Univ.), Alain Molinie (Lamont-Doherty Geol. Observ.), James Ogg (Purdue Univ.), A. R. M. Salimullah (Univ. Southampton), Maureen Steiner (Univ. Wyoming), Brian Wallick (Purdue Univ.) and Winton Wightman (Daihousie Univ.).

data from these seismic surveys, ODP sites 800,801 and 802 were selected and subsequently drilled on Leg 129 . Site 800 yielded only dolerite sills, and 802 basaltic lava flows, both of Cretaceous age. But at site 801 , Jurassic sediments and extensive basement were uncovered after drilling through 200 metres of mid-Cretaceous

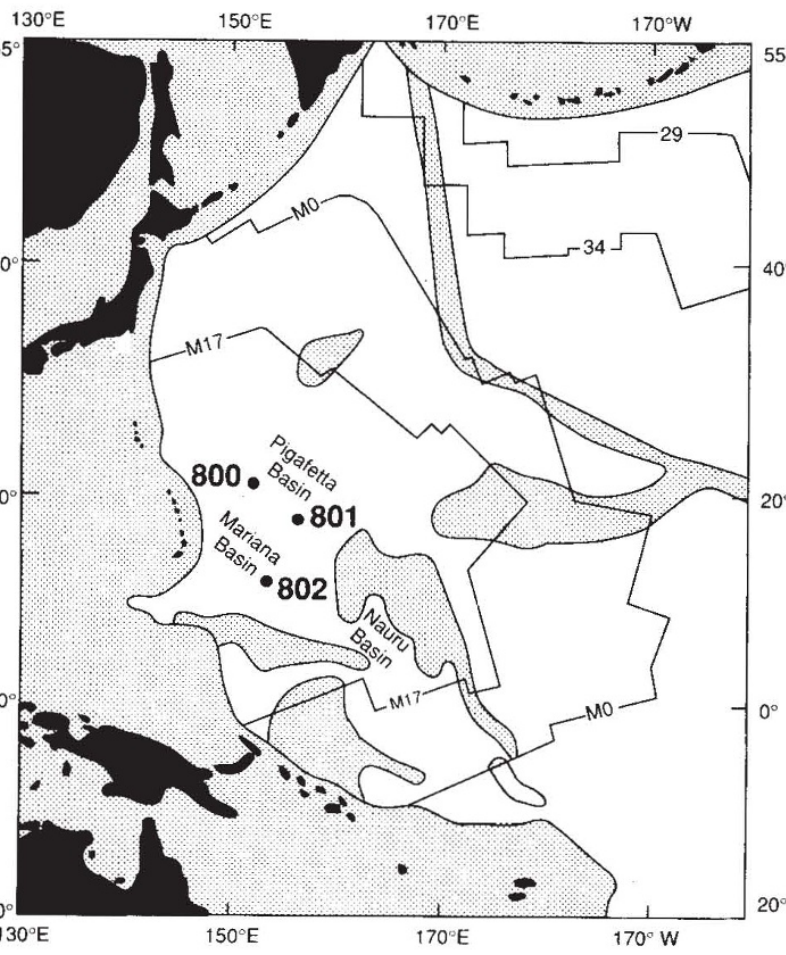

Coring site locations for ODP Leg 129 in the western Pacific Ocean. White portions of the map represent areas of normal cean crustal thickness and water depth on the Pacific plate, and grey areas represent volcanic edifices with thickened crustal sections, as well as the younger areas beyond the Pacific ubduction zones. Magnetic lineation isochrons ${ }^{2}$ correspond to the following geological boundaries: M17, Jurassic/Cretaceus; M0-Barremian/Aptian; M34, Santonian/Campanian; and 9, Cretaceous/Tertiary.

\section{(Albian) volcaniclastic turbidites.}

The Upper Jurassic sedimentary section at site 801 contains marine fossils thought to be from the giant ocean that surrounded the supercontinent Pangaea at that time. The fossils are mainly radiolarians - plankton with a silica shell. The section comprises 70 metres of brown radiolarite together with an abundance of manganese oxide and dark brown chert. This material is underlain, probably unconformably, by 20 metres of red radiolarite and claystone of Callovian age which are heavily ironenriched, giving them their colour. Biostratigraphic dating is based on a recently developed radiolarian stratigraphy ${ }^{4}$ for the Pacific. The basal sediments are believed to have been deposited during the Middle Jurassic near the Callovian/ Bathonian boundary, but the oldest strati- graphic age has yet to be confirmed by radiometric dating of the underlying basalts.

Magnetic remanence measurements and microfossil abundances suggest that the Pacific plate was formed north of the Equator during the Middle Jurassic; it moved south across the Equator at the end of the Jurassic and then started to go north in the mid-Cretaceous. Since then, it has moved northwards continuously to where it is now. It is significant that the fossils recovered are mainly composed of silica, as opposed to carbonate, showing that there was very little carbonate production and/or preservation in the Jurassic 'superocean'.

In holes $801 \mathrm{~B}$ and $801 \mathrm{C}$, we drilled through igneous basement to 131 metres below the interface between sediment and crust, with a 20 -metre section of overlap between the two holes. The basement is made of interlayered lava flows and pillow basalts. From the physical appearance of the basalts, it seems that they were extruded mainly under submarine conditions and, from their location beneath Callovian/Bathonian sediments, that they were emplaced sometime during the Middle Jurassic.

Forty stratigraphic layers were recovered from the oceanic crust at site 801 . Extrusive flows, mainly aphyric basalts, made up much of the material, although there were some microphyric and phyric basalts with olivine and plagioclase phenocrysts. We also recovered 3 metres of a hydrothermal deposit from about 60 to 70 metres below the top of the basement. The deposit probably consisted of iron oxides/hydroxides which have been well cemented, and largely replaced by silica. The pillow basalts beneath the deposit had been altered, presumably by the action of the same hot-water solutions responsible for the hydrothermal deposit. This deposit is remarkable - it is particularly well preserved, probably because it became buried beneath extrusive flows soon after its deposition.

During Leg 129, no logging or other geophysical measurements were carried out in the basement part of hole $801 \mathrm{C}$. But the hole has remained stable and clean, thus presenting a golden opportunity for further investigation of this section of oceanic crust.

\footnotetext{
. Handschumacher, D. W. et al. Tectonophysics 155, 365-

$380(1988)$. Larson, R. L. et al. The Bedrock Geology of the World
2. (Freeman, New York, 1985)

3. Abrams, L. S. et al. Trans. Am. geophys. Un. 69, 1442 (1988).

4. Matsuoka, A. \& Yao, A. Mar. Micropaleontology 11, 91 105 (1986)
} 